\title{
INFLUENCE OF LASER POWER ON THE MICROHARDNESS AND WEAR RESISTANCE PROPERTIES OF LASER METAL DEPOSITED 17-4 PH STAINLESS STEEL
}

\author{
A. Adeyemi ${ }^{1}$ E. T. Akinlabi1, R. M. Mahamood1,2,* \\ ${ }^{1}$ Department of Mechanical Engineering Science, University of Johannesburg, Auckland Park, \\ Kingsway Campus, Johannesburg, 2006, South Africa \\ ${ }^{2}$ Department of Mechanical Engineering University of Ilorin, Ilorin, 23400003, Nigeria \\ * Corresponding author's e-mail address: mahamoodmr2009@gmail.com
}

\begin{abstract}
This aim of this research is to investigate the impact of laser power on the hardness and the wear resistance properties of laser metal deposited 17-4 PH stainless steel. Hardness was studied using the Zwick/Roell microhardness tester and the wear resistance property was carried out using the ball-on-disc Anton Paar-tribometer wear tester. The study revealed that an irregular increase and decrease in the average hardness value and wear behaviour were observed. This could be attributed to the presence of copper precipitate which was more concentrate at the overlapping region because of the reheating activity that is happening between the succeeding and preceding track layers.
\end{abstract}

KEYWORDS: Laser Metal Deposition, Laser power, 17-4 PH stainless steel, microhardness, wear resistance.

\section{ACKNOWLEDGEMENTS}

The author acknowledges the financial support of the Global Excellent and Stature (GES), University of Johannesburg and The National Laser Centre Council for Scientific and Industrial Research (NLC-CSIR) in Pretoria, South Africa for the rental pool grant.

\section{REFERENCES}

[1] Yoo W. D., Lee J. H., Youn K. T., Rhyimd Y. M., Study on the Microstructure and Mechanical Properties of 17-4 PH Stainless Steel depending on Heat Treatment and Aging Time, Solid State Phenomena, 118, 2006, pp. 15-20.

[2] Smith, W.F., Structure and Properties of Engineering Alloys, 2nd ed., McGraw-Hill, Inc. New York, USA, 1993, pp. 328-335.

[3] Mahamood R. M., Akinlabi E. T., Advanced Noncontact Cutting and Joining Technologies: Micro- and Nano-manufacturing, Springer Science Publisher, Switzerland, 2018.

[4] Mahamood R. M., Akinlabi E. T, Shukla M., Pityana S., Revolutionary additive manufacturing: an overview, Lasers in Engineering, 27, 2014, pp. 161- 178 .

[5] Stern A., Rosentha Y., Berger A., Ashkenazi D., Additive Manufacturing - From Fundamentals to Applications, Annals Of "Dunarea De Jos" University, Fascicle XII, Welding Equipment and Technology, 28, 2017, pp. 51-58.

[6] Rosenthal A., Tiferet E., Ganor M., Stern A., post-Processing of AM-SLM Alsi10mg Specimens: Mechanical Properties and Fracture Behaviour, Annals Of "Dunarea De Jos" University, Fascicle XII, Welding Equipment and Technology, 26, 2015, pp. 33-38.

[7] Rosenthal I., Tiferet E, Ganor M., Stern A., Selective Laser Melting Additive Manufacturing: Alsil0mg Powder Characterization, Annals Of "Dunarea De Jos" University, Fascicle XII, Welding Equipment and Technology, 25, 2014, pp. 35-40

[8] Rosenthal I., Sharon R., Shwartzman Z., Stern A., Hatching Strategy: 3D Visualization Model for Powder Bed Based Additive Manufacturing with Focused Beams, Annals Of "Dunarea de Jos" University, Fasc. XII, Welding Equipment and Technology, vol. 25, 2014, pp. 13-18.

[9] Berger A., Sharon Y., Ashkenazi D., Stern A, Test Artefact for Additive Manufacturing Technology: FDM and SLM Preliminary Results, Annals Of "Dunarea de Jos" University, Fasc. XII, Welding Equipment and Technology, vol. 27, 2016, pp. 29-37.

[10] Mahamood R. M., Akinlabi E. T., Effect of Processing Parameters on Wear Resistance Property of Laser Material Deposited Titanium - Alloy Composite, Journal of Optoelectronics and Advanced Materials (JOAM), 17(9-10), 2015, pp. 1348 - 1360.

[11] Pityana S., Mahamood R. M., Akinlabi E. T., Shukla M., Effect of gas Flow Rate and powder flow rate on Properties of Laser Metal Deposited Ti6Al4V, 2013 International Multi-conference of Engineering and Computer Science (IMECS 2013), 2013, pp. 848-851.

[12] Shukla M., Mahamood R. M., Akinlabi E. T., Pityana S., Effect of Laser Power and Powder Flow Rate on Properties of Laser Metal Deposited Ti6Al4V, World Academy of Science and Technology, vol.6, 2012, pp. 44-48.

[13] Mahamood R. M., Akinlabi E. T., Owolabi M. G., Laser Metal Deposition Process for Product Remanufacturing. In: Gupta K. editor. Advanced Manufacturing Technologies. Springer, Switzerland, 2017, pp. 267-291. 
[14] Mahamood R. M., Laser Metal Deposition Process of Metals, Alloys, and Composite Materials, Springer, 2018.

[15] Mahamood R. M., Akinlabi E. T., Functionally Graded Materials, Springer Science Publisher, Switzerland, 2017.

[16] Mahamood R. M., Akinlabi E. T., Laser Additive Manufacturing. In Advanced Manufacturing Techniques Using Laser Material Processing, IGI Global 2016, pp. 1-23.

[17] Yu J., Rombouts M., Maes G., Cracking behaviour and mechanical properties of austenitic stainless steel parts produced by laser metal deposition. Materials \& Design, 45, 2013, pp. 228-235.

[18] Zhang K., Wang S., Liu W., Shang X., Characterization of stainless steel parts by Laser Metal Deposition Shaping, Materials and Design, 55, 2014, pp. $104-119$.

[19] Yadollahi A., Shamsaei N., Thompson S. M., Seely D. W., Effects of process time interval and heat treatment on the mechanical and microstructural properties of direct laser deposited 316L stainless steel, Journal of Materials Science and Engineering. A644. 2015, pp. 171 183.

[20] Guo P., Zou B., Huang C., Gao H., Study on microstructure, mechanical properties and machinability of efficiently additive manufactured AISI 316L Stainless steel by high-power direct laser deposition, Journal of Material Processing Technology, 240, 2016, pp. 12 $-22$.

[21] Wang Z., Palmer T. A., Beese A. M., Effect of processing parameters on microstructure and tensile properties of austenitic stainless steel 304L made by directed energy deposition additive manufacturing, Acta Materialia, 110, 2016, pp. 226 - 235.

[22] Bayode A., Akinlabi E. T., Pityana S., Characterization of laser metal deposited 316L stainless steel, Lecture notes in engineering and computer science, 1, 2015, 925-928.

[23] Bayode A., Akinlabi E. T., Pityana S., Microstructure and microhardness of 17-4 PH stainless steel made by laser metal deposition. Lecture notes in engineering and computer science, $12016,812-814$

[24] *** ASTM E384-11e1, Standard test method for Knoop and Vickers Hardness of materials, ASTM international book of standards 03(01) 2011

[25] *** ASTM Standard G99-05, Standard Test Method for Ball-on-disc Sliding Wear, Annual Book of ASTM Standard 2007.

[26] Mahamood R. M., Akinlabi E. T., Shukla M. Pityana S., Characterizing the Effect of Laser Power Density on Microstructure, Microhardness and Surface Finish of Laser Deposited Titanium Alloy, Journal of Manufacturing Science and Engineering, 135-6, 2013, 064502-064502, doi:10.1115/1.4025737.

[27] Adeyemi, A. A., Akinlabi, E. T., Mahamood, R. M., Sanusi, K. O., Pityana, S., Tlotleng, M., Influence of laser power on microstructure of laser metal deposited 17-4 PH stainless steel. In IOP Conference Series: Materials Science and Engineering, 225(1), 2017, pp. 012028.

[28] *** Pin-on-disk ANTON PAAR Tribometer (GmbH) Manual, Strasse 208054, Austria.

[29] Mahamood R. M., Akinlabi E. T, Shukla M., Pityana S., Scanning Velocity Influence on Microstructure, Microhardness and Wear Resistance Performance on Laser Deposited Ti6Al4V/TiC Composite, Materials and Design, 50, 2013, pp. 656-666. 